\title{
Reseña del libro Cosmos. Una ontología materialista de Michel Onfray (2016)*
}

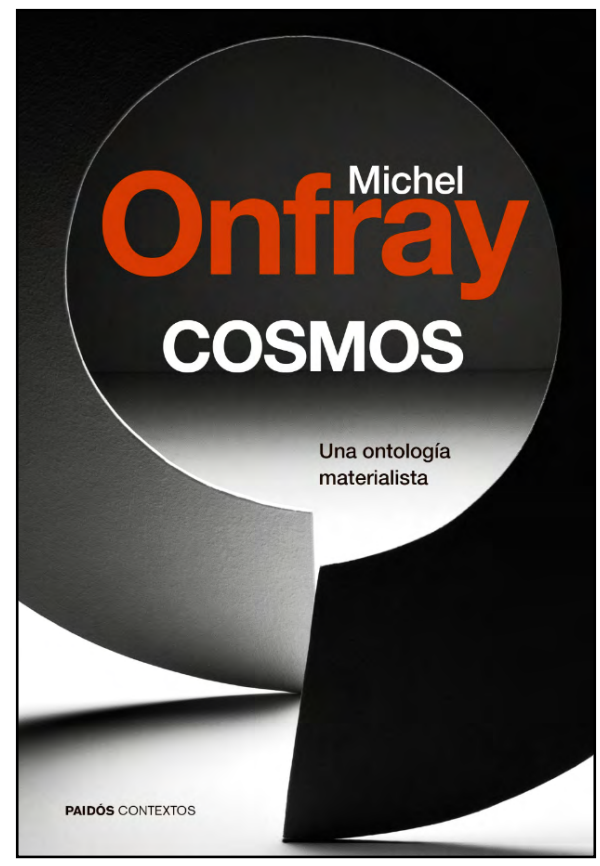

Portada del libro Cosmos. Una ontología materialista

Fuente: Onfray (2016).

Claudia Arcila Rojas

Universidad de Antioquia, Medellín, Colombia claudiarbol@gmail.com http://orcid.org/0000-0003-4621-0866

Cómo citar: Arcila Rojas, C. (2020). Cosmos. Una ontología materialista. Michel Onfray. Ciencias Sociales y Educación, 9(18), 317-322. https://doi.org/10.22395/csye.v9n18a17

Recibido: 19 de febrero de 2020.

Aprobado: 10 de marzo de 2020. 
En la libertad a la que me siento autorizada por Onfray cuando me acerco a sus textos y me encuentro con su vitalidad de la que hago parte en sus composiciones de sentido, me arriesgo a compartir las implicaciones emocionales e intelectuales que me han acontecido con la lectura de su libro Cosmos. Una ontología materialista, a la luz y a la sombra de mis propias circunstancias. Reitero que esta libertad viene dada por el mismo hecho de que el autor pone sobre el telar de la escritura su palpitación existencial atravesada por los acontecimientos de dolor, melancolía y añoranzas. Es un tejido donde su niñez es la apertura a un paisaje de memorias conjugadas con el propio paisaje cósmico que deviene en misterios de belleza y manifestaciones de sabiduría.

Cosmos es el paginado de constelaciones que hacen del lenguaje un movimiento donde el arriba y el abajo pueden definirse como "el abismo más íntimo de las cosas" (Nietzsche, 1977, p. 167); como el vértigo de todo aquello que nos pone ante los acantilados del sueño y sus caídas impetuosas y desmorona nuestra torre mental para darle nacimiento a la música en las imágenes de la tragedia.

Serán pues mis propias memorias las que harán parte de este camino por un Cosmos en el cual pueden leerse todas las órbitas estéticas de Nietzsche $\mathrm{y}$, por lo mismo, todas las pulsiones vitales que nos invitan a recorrer los subterráneos de nuestro subconsciente para darle libertad y morada a esas sombras en nuestro consciente. Por ello, asistida por los estados de oscuridad y luminosidad, nombro mi experiencia con este texto como un viaje íntimo entre los vacíos de un laberinto; entre las soledades que se hospedan en el espacio del dormir y el soñar donde "la naturaleza produce unos efectos salvadores y auxiliadores" (Nietzsche, 1977, p. 42).

Es, sin duda, en la naturaleza donde Onfray extiende toda la estética de la vida en la potencia de la abundancia que se encuentra en una semilla al expresarse como principio de la cosecha, del alimento, del ágape para descubrir el espacio, el tiempo y las conexiones con la tierra:

Uno no vive ni puede sobrevivir si no sabe dónde, cuándo y cómo plantar, sembrar, desmalezar, layar, curar, cosechar, arar. En esta configuración primitiva, el no saber lleva a lo peor: la escasez, el hambre, la muerte de los suyos. (Onfray, 2016, p. 340)

Esa naturaleza que es la tierra, el agua, el aire, el fuego, las plantas, los animales, la oscuridad, el bosque, el desierto, la geografía en su laberíntica espacio-temporalidad planetaria y placentaria; esos espacios donde la filosofía vuelve a la profundidad de lo simple para generar la transformación que justifica la vida como un ser otro (Pessoa, 2008); es la transformación del camello al león y del león al niño (Nietzsche, 2011). Es la transformación en el nomadismo 
de la inocencia y en la pregunta que desnuda nuestra ignorancia y nos pone en esa migración infinita e indefinida; en ese peregrinaje de la contemplación que supera la distancia para oler y degustar el mundo: "La civilización ha desnaturalizado $[\ldots]$ al animal que somos para transformarnos en observadores del mundo al precio de una deplorable incapacidad para olerlo y degustarlo" (Onfray, 2016, p. 38).

De esta manera, regresamos la vida y el tiempo a nuestro cuerpo; desplegamos la escritura que somos en testimonio del baile cósmico, del arrojo dionisíaco en memoria de las vibraciones celestes y de sus espirales zodiacales; volvemos otra vez a la rueda de los animales y a sus cualidades cósmicas que también son nuestras, pero a las que hemos renunciado por las lógicas de una civilización castrante:

La duración vivida no se percibe naturalmente, se mide culturalmente. Nuestro cuerpo la vive sin saberlo; nuestra civilización la mide para enjaularla, para domarla, para domesticarla. La civilización es el arte de transformar en tiempo mensurable, por lo tanto rentable, una duración corporal escrita que da testimonio de la permanencia en nosotros del ritmo cósmico que se nos hace necesario conocer. (Onfray, 2016, p. 30)

Es necesario entonces devolver el pensamiento a las imágenes del afuera despojadas de las pretensiones de saber y de poder propias de la civilización. Es necesario volver a ese afuera que somos nosotros mismos en las intuiciones del "tiempo circular de las estaciones, tiempo cíclico del cosmos, tiempo de la rueda oriental" (Onfray, 2016, p. 388). Es necesario girar para que la vida no agote su torrente natural expresado en grandes misterios donde la calamidad y el horror también hacen parte de la ceremonia vital.

En la Grecia antigua, señala Nietzsche (1977), la belleza gobernó sobre lo insoportable. Era la sensibilidad de un pueblo fortalecido por la desdicha y redimido en la cicatriz que su desgracia otorga. La memoria hacia la plasticidad de las proyecciones artísticas invierten el dolor en alegría, pues únicamente en la desmesura musical sale la verdad de su reclusión: "La desmesura se desveló como verdad, la contradicción, la delicia nacida de los dolores hablaron acerca de sí desde el corazón de la naturaleza" (Nietzsche, 1977, p. 59). Onfray (2016) también recorre la composición del cosmos en la delicia nacida de los dolores que le permitieron hablar de sí desde el corazón de la naturaleza. La muerte de su padre constituyó el impulso para esta narración filosófica en contacto y contemplación del mundo. Recorrió los paisajes de la naturaleza y encontró en ellos la sabiduría y el sosiego donde el tiempo de la palabra es también el desnudamiento de la fragilidad y de los temores ante el palpitar de un acontecimiento incierto. 
En este sentido, el tiempo es un telar de recuerdos que nos han de retornar a dialogar con la soledad que trae voces muy viejas y lejanas; voces que retumban en nuestra interioridad y que nos impulsan a espacios en fuga; movimientos de la memoria en imágenes que insisten en convocarnos a no romper el hilo entre el adentro y el afuera que somos; entre el arriba y el abajo que nos seduce a recuperar el tiempo ceremonial con la vida, su desgaste y finitud. Por ello, Onfray (2016) nos invita a movernos en pregunta; a recuperar ese tiempo en conciencia de lo que somos y dejamos de ser, de lo que hacemos en relación con los otros, con lo otro:

¿Cómo capturar entonces el tiempo del vino y el tiempo de los campesinos, el tiempo del geólogo y el del espeleólogo, el tiempo de los nómadas y el de los sedentarios, el tiempo de los rurales y el de los urbanos, el tiempo de las plantas y el de las piedras, el tiempo de los vivos y el de los muertos? (p. 105)

Ahora bien, lo que somos y dejamos de ser, se ha desdoblado en una especie de metamorfosis retrospectiva en la cual nos vemos como semilla, larva, arbusto, jardín, desierto, enredadera, reptil, cazador, agricultor, vino, viñedo, víctima y victimario de un camino de remembranzas donde no somos lo que hemos creído. Hemos sido en el plural de lo inconcluso que se extiende como incertidumbre en escritura; en un plural que conduce por los oleajes placentarios como profundidad de un cosmos en la más tibia armonía de la existencia: "La identidad se constituye desde el vientre de la madre" (Onfray, 2016, p. 61) y empieza a ser un epistolario en los rostros de una escritura que nos trasciende y nos devuelve por trayectos desconocidos.

Escribir se convierte, entonces, en una experiencia puesta ante un horizonte de incertidumbre frente a la cual logramos contemplar la disolución de lo que somos: el desvanecimiento de toda idea de llegada, de cumplimiento, de respuesta. Este es el camino interminable del error o, si se quiere, del errar sin pretender un rumbo fijo. Por el contrario, se transita en la escucha de esas voces que parecen invitarnos a dialogar con páginas olvidadas de la belleza, con preguntas desafiantes sobre la vida y aprendizajes sombríos sobre la muerte. La belleza de la vida palpita en el cosmos sin estratos, sin jerarquías, sin regímenes de poder o de saber, sin categorizaciones epistemológicas ni protocolos de vigilancia, control o castigo. La belleza del cosmos tiene una diversidad vital nos integra en el mismo ecosistema:

El mundo, la naturaleza, las aves, el río, las flores, la luna y el sol, los peces, las plantas, los bosques, las planicies, los perros, las luces, los colores, las estaciones, las ranas, los niños, los ratones, las libélulas no son sino variaciones de un único y mismo tema: el cosmos. (Onfray, 2016, p. 381) 
Con estos trayectos de conciencia, Onfray rompe las rutas prescriptivas de la filosofía que ha estado enclaustrada en los discursos de la razón sometida a los códigos ideológicos del esclavismo; ajustada a las actuaciones de producción clasista; ilustrada e instrumentalizada en la publicidad capitalista y en sus dictámenes binarios. Hay una suerte de prosa íntima que se declara como una contrahistoria de la filosofía para moverse por los territorios de la alquimia cuya cultura es "el saber de la naturaleza, el conocimiento del cosmos, la ciencia de la tierra" (Onfray, 2016, pp. 340-341); la sabiduría ancestral que nos conduce a mirarnos en el espejo de la luna, a palpitar con el latido de las estrellas, a despertar con los rayos del amanecer y el canto de las aves; a silenciarnos con las tormentas que le dan voz al mar y a la nieve; a nombrarnos con las flores, las plantas, los árboles, las montañas; a correr con los lobos, dormir y dialogar con los gatos; a sentir la salud y la alegría de un alimento que no somete a sacrificios ni se justifica en cadena alimenticia alguna. La sabiduría ancestral nos conduce a la profundidad del bosque para volver a escuchar las entidades del agua, de la tierra, del aire y del fuego; para volver a escucharnos mientras morimos y renacemos en este cuenco cósmico fuente de la "fuerza natural, sana y creadora" (Nietzsche, 1977, p. 179); es un recinto musical donde el baile nos conduce a las resonancias íntimas en "un juego artístico que la voluntad juega consigo misma, en la eterna plenitud de su placer" (Nietzsche, 1977, p. 188).

En estas fuerzas liberadoras de nuestra alma dionisíaca, siento el impulso onírico que pone el afuera en mi más cercana intimidad, con las sombras y con las luces que revelan mi fracción cósmica, y me acercan a la memoria de pertenencia a un torrente vital enigmático, arrollador y bello. Son memorias del sueño que también pueden ser retazos dispersos de vivencias atravesadas por el filo del olvido y, por ello, imágenes turbias que tejen sombras de la noche, encantamientos del bosque, temores y deseos por el inframundo. Pero también son silencios que parecen proteger o protegerse de lo innombrable; silencios que pueden trascender a una palabra sin pretensiones de lucidez; palabras que revelan la ignorancia, libres de toda aprobación o aplauso; palabras que juegan dentro de su propio trenzado de libertad y fracaso; palabras insurrectas de las ataduras del saber y del poder y, por lo mismo, es un lenguaje que habita el estoicismo que se fuga de toda imprecación de la realidad y sus dominios de vigilancia, control y sometimiento.

Ahora bien, Aunque Onfray (2016) afirma que "[e]l tiempo del cosmos, un orden plurimilenario, ha desaparecido en provecho del tiempo de las máquinas de producir virtualidad" (p. 104), es necesario refugiarnos en el silencio que se envuelve en los pliegues de la levedad para ponernos en el escenario del afuera; en el vértigo con el vacío donde el resplandor incesante del misterio 
aparece en medio de la totalidad del espacio y su indefinición ante el cosmos que nos devuelve el vínculo auténtico con el mundo:

los hombres mantenían relaciones directas con el mundo; en otras palabras, con la eterna sucesión del día y de la noche, con los ciclos de las estaciones, con la alternancia de las luces y de las tinieblas, con las estrellas en el cielo y con los misterios de las grutas bajo la tierra, con los movimientos de los astros, con los trayectos de la Luna y el Sol en el cosmos, con la regularidad de metrónomo de las apariciones de los solsticios y los equinoccios, con la dialéctica de la primavera y el invierno, con el perpetuo contrapunto de los cadáveres enterrados y de los niños que brotan del vientre de sus madres (Onfray, 2016, p. 297).

Es necesario, incluso, retornar a la potencia de la virtualidad para escaparnos de sus tentáculos mientras jugamos con las identidades nómadas; con los rostros musicales del amanecer que nos llevan a las cumbres de las montañas; con los rostros silenciosos que deambulan por las orillas de los ríos; con los rostros de la vida nocturna que también son los rostros de la muerte: rostros olvidados que renacen en nuestro propio rostro indefinido.

\section{Referencias}

Nietzsche, F. (1977). El nacimiento de la tragedia. Alianza Editorial.

Onfray, M. (2016). Cosmos. Una ontología materialista. Editorial Paidós.

Pessoa, F. (2008). Vivir es ser otro. El libro del desasosiego. Seix Barral. 